\title{
Quantitative Reflectance Spot Test for the Determination of Acetylsalicylic Acid in Pharmaceutical Preparations
}

\author{
Francisco A. A. Matias ${ }^{\#}$, Marta M. D. C. Vila and Matthieu Tubino* \\ Instituto de Química, Universidade Estadual de Campinas, CP 6154, 13084-971 Campinas - SP, Brazil
}

\begin{abstract}
Este trabalho descreve um método para a determinação quantitativa de ácido acetilsalicílico (ASA) utilizando procedimento "spot test" e reflectância difusa. O método é baseado na formação do complexo de cor roxa intensa entre o ácido salicílico, obtido a partir da hidrólise alcalina do ASA, e íons Fe(III). O procedimento proposto permite a análise de medicamentos contendo ASA de forma fácil e simples, uma vez que não é necessário fazer separações. A reflectância da mistura final, colocada sobre um disco de papel de filtro, é medida diretamente. Foram analisados nove medicamentos comerciais contendo ASA cujos resultados apresentaram um desvio padrão relativo médio de $0,9 \%$. O limite para a determinação quantitativa é de $0,6 \mathrm{mg}$ de ASA na solução de trabalho. As análises feitas com o método proposto foram comparadas com outras análises, das mesmas amostras, segundo o procedimento recomendado pela "United States Pharmacopoeia", onde se observou um desvio padrão relativo de $0,6 \%$. Compararam-se os dois métodos utilizando-se o teste $t$ de Student. Para um grau de liberdade $v=4\left(v=\mathrm{n}_{1}+\mathrm{n}_{2}-2\right)$ e um limite de confiança $\alpha=0.05$, onde $t=2,78$, todos os resultados foram concordantes.
\end{abstract}

This paper describes a quantitative reflectance spot test procedure for the determination of acetylsalicylic acid (ASA) in pharmaceutical preparations. The method is based on the reaction of salicylic acid, obtained from the hydrolysis of ASA, with Fe(III) forming a deep blue-violet compound. Medicines containing ASA can be easily analyzed by the proposed method as it is not necessary to do any separation. The final mixture is placed on a sheet of filter paper, and the reflectance is directly measured. Nine commercial medicines containing acetylsalicylic acid were analyzed with the proposed method. The mean RSD was $0.9 \%$. Results were compared with those obtained with the United States Pharmacopoeia recommended procedure (RSD 0.6\%). The quantitative detection limit is 0.6 mg ASA in the working solution. For a degree of freedom $v=4\left(v=\mathrm{n}_{1}+\mathrm{n}_{2}-2\right)$ and a confidence coefficient $\alpha=0.05$ all the results agree under the tabulated $t$-Student test value (2.78).

Keywords: acetylsalicylic acid, spot test, quantitative analysis, reflectance, pharmaceutical preparations

\section{Introduction}

Acetylsalicylic acid (ASA) is a remedy with antiinflammatory, analgesic and anti-pyretic properties. It was synthesized in 1897 in a pure and stable form, by Dr. Felix Hoffmann, in the laboratories of the "Farbenfabrik Freidrich Bayer", in Elberfeld, Germany. It was introduced in the medical clinic two years later with the name "aspirin", i.e., "a" from acetyl and "spir" from the family plants Spirea that contains derivatives of the salicylic acid. ${ }^{1}$

The anti-pyretic and analgesic efficiency of ASA was promptly comproved, however only after the years 1940 it

\footnotetext{
* e-mail: tubino@iqm.unicamp.br

\# Present Address: Departamento de Química, Universidade Federal de Santa Catarina, CP 476, Trindade, 88040-900 Florianópolis - SC
}

began to be employed in higher doses as anti-inflammatory. When its mechanism of action began to be understood ${ }^{2}$ the possibility for use against cardiac and circulatory disturbs became evident. ${ }^{3}$

The consumption of ASA is always increasing and corresponds to several tons per year. For instance, in 1997 it was claimed that it could to be as high as 20000 tons only in the United States. ${ }^{4}$

ASA is one of the oldest medicines that yet plays an important role in the modern therapeutics. The main metabolite of the ASA is the salicylic acid that results from its hydrolysis and can be qualitatively determined giving indirectly the quantity of the former. The determination of ASA in pharmaceutical preparations is important for assessment of their quality and, in blood serum, to control therapies based on this compound and for toxicological 
procedures. Intoxication accidents with children, for instance, are not rare due to the accessibility of this drug. ${ }^{5}$

The acid-base titration, ${ }^{6}$ as well as the spectrophotometric methods exploiting Trinder's reaction ${ }^{7}$, are based on the hydrolysis of the acetylsalicylic acid. Trinder's procedure involves the formation of a deep blue-violet complex formed between salicylic acid and Fe(III). Some spectrophotometric flow injection methods, using on line hydrolysis, have been developed. ${ }^{8}$

Ultra-violet, ${ }^{9}$ fluorescence ${ }^{10}$ and infra-red ${ }^{11}$ spectrophotometric methods have been also described for the determination of ASA and salicylic acid in pharmaceutical preparations. However it seems that they are not frequently used, possibly due the difficult and tedious preparations of the samples. Chromatographic procedures are also used, mainly HPLC. ${ }^{12}$ Methods using atomic absorption spectrometry have been also applied. ${ }^{13}$ These methods, however, involve expensive apparatus and usually need extraction procedures.

Ion selective electrodes have been developed showing high specificity, good detection limits and relatively low cost. $^{14-17}$

Biosensors and bioreactors based on the enzyme salicylate hydroxylase have been also employed. They are highly specific and can detect very low concentrations. Despite the high price of the enzyme, they can be anchored on a fixed support and be used several times, thus decreasing the cost per analysis. ${ }^{18-20}$

The analysis of pharmaceutical preparations has as objective not only the industrial quality control but also the idoneousness of the product. Recently, in Brazil, a number of medicines were falsified, from antipyretic to contraceptives, antibiotics, anti-cancerigenous etc. with serious consequences. In order to restrain facts like these, it is important to develop rapid, low cost and simple analytical procedures, which can be used without sophisticated apparatus, in locus, yielding reliable results. In this aspect, spot test procedures can be a very good alternative. This kind of methods has been currently used, for example, for the qualitative detection of intoxications in biological fluids, as blood and urine. ${ }^{21}$

The visual qualitative spot test is based on a change of color when a chemical reaction between the analyte and the utilized reagent takes place. This color change is proportional to the analyte concentration, therefore quantitative spot test procedures can be envisaged. In this paper, the concentrations of ASA in several commercial pharmaceutical preparations were determined, using a reflectance procedure based on the reaction of the salicylic acid with Fe(III) forming a deep blue-violet compound.

A very simple homemade reflectometer was used. The apparatus is essentially composed by a light emitter diode (LED) and a light dependent resistor (LDR). ${ }^{22}$

\section{Experimental}

\section{Reagents and solutions}

All reagents used were of analytical grade quality. The water used to prepare the solutions was first distilled in a glass distiller and then passed through a Milli QPlus deionizer. The solutions were prepared as follows.

Sodium hydroxide solution $\left(0.5 \mathrm{~mol} \mathrm{~L}^{-1}\right) .2 .0 \mathrm{~g} \mathrm{NaOH}$ were dissolved in water and diluted to $100 \mathrm{~mL}$.

Nitric acid solution $\left(1.0 \mathrm{~mol} \mathrm{L^{-1 }}\right) .62 .5 \mathrm{~mL}$ of concentrated nitric acid were diluted to $1.0 \mathrm{~L}$ with water.

Iron III solution. $9.35 \mathrm{~g} \mathrm{Fe}\left(\mathrm{NO}_{3}\right)_{3} \cdot 9 \mathrm{H}_{2} \mathrm{O}$ were dissolved in $100.0 \mathrm{~mL}$ of water.

\section{Analytical curve}

The analytical curve was obtained in the same way as described in the procedure bellow, using six different aliquots containing $0.0,1.2,3.0,5.1,10.0$ and $13.2 \mathrm{mg}$ ASA. The filter paper used as support for the spot was considered as the blank. Three reflectance measurements were performed for each aliquot and also for the blank, and the mean value was considered.

\section{Analytical procedure}

Dissolve carefully an aliquot of the pharmaceutical preparation, containing about $10 \mathrm{mg}$ ASA, in $1.00 \mathrm{~mL}$ of an aqueous solution of $\mathrm{NaOH} 0.5 \mathrm{~mol} \mathrm{~L}^{-1}$. Then add 1.00 $\mathrm{mL}$ of $\mathrm{HNO}_{3} 1.0 \mathrm{~mol} \mathrm{~L}-1$ solution. The $\mathrm{pH}$ of this final solution should be about 2.5. Add 2 drops (about $0.10 \mathrm{~mL}$ ) of the Fe(III) solution. A deep blue-violet color is developed. Place two drops of this solution on a filter paper. A spot with about $3 \mathrm{~cm}$ in diameter is formed. Perform reflectance measurements directly on the spot.

\section{Results and Discussion}

The analytical curve is a straight line. Resistance values of the light dependent resistor are linearly related to the acetylsalicylic acid contents of the aliquot from 0 up to $13.2 \mathrm{mg}$. Beyond this amount of ASA, formation of a blue precipitate is observed and the measured resistance values deviate form the straight line.

The analytical curve is described by the equation $\mathrm{R}=246+10.7 \times \mathrm{C}_{\mathrm{ASA}}$, where $\mathrm{R}$ is the measured resistance, in kohm, and $\mathrm{C}_{\mathrm{ASA}}$ is the ASA contents of the aliquot, 
in mg. The observed correlation coefficient is 0.997 $(\mathrm{n}=6)$.

The detection limit is about $0.6 \mathrm{mg}$ ASA in the working solution described above in the analytical procedure. However, even in medicines containing low ASA quantities is always possible to weight a portion in order to obtain an amount of about $10 \mathrm{mg}$. Therefore, the quantitative detection limit can be easily improved.

Table 1 shows the acetylsalicylic acid concentration of nine samples, analyzed by the United States Pharmacopoeia method and by the proposed procedure. Three aliquots were used for each sample. The statistical $t$-Student test was applied to compare the results obtained by the two analytical methods..$^{23}$ Considering that for the degree of freedom $(v) 4$ the tabulated $t$ value is $2.78(\alpha=$ $0.05)$, no significant differences were observed between the results obtained by the two methods at the $95 \%$ confidence level. The medicine samples were purchased in the local market. All contain starch and/or lactose. Some contain dyes, flavors and other compounds. In this case additional informations are introduced in Table 1. The experimental results are shown normalized to $100.0 \%$ as the analyzed medicines contained different nominal quantities of ASA, from $100 \mathrm{mg}$ to $500 \mathrm{mg}$ per tablet. Normalization allows better comparison of the results obtained with the nine medicines independently of the ASA content. Also, in this manner, the relative confrontation of the ASA nominal content of the analyzed medicines is easily done.

The analytical results obtained with this method should be understood as the total content of salicylic acid

Table 1. Contents of ASA in different samples as determined by the United States Pharmacopoeia method and by the spot test proposed in this work. The ASA contents of the tablets were normalized to $100.0 \% \pm$ RSD. Tabulated value for the degree of freedom $(v) 4$ is $2.78(\alpha=0.05) ; v=\mathrm{n}_{1}+\mathrm{n}_{2}-2$ and $\mathrm{n}_{1}=\mathrm{n}_{2}=3$ in this instance

\begin{tabular}{cccc}
\hline Sample & $\begin{array}{c}\text { Pharmacopoeia } \\
\text { method } \\
(\%)\end{array}$ & $\begin{array}{c}\text { Proposed } \\
\text { method } \\
(\%)\end{array}$ & $\begin{array}{c}\text { Calculated } \\
t \text {-Student } \\
\text { value }\end{array}$ \\
\hline 1 & $98.8 \pm 0.6$ & $99.3 \pm 0.8$ & 0.707 \\
2 & $99.1 \pm 0.7$ & $98.3 \pm 0.9$ & $0.992^{a}$ \\
3 & $97.2 \pm 0.9$ & $98.3 \pm 0.8$ & 1.29 \\
4 & $100.7 \pm 0.4$ & $99.7 \pm 0.7$ & $1.75^{a}$ \\
5 & $97.5 \pm 0.9$ & $96.2 \pm 0.7$ & $1.61^{b}$ \\
6 & $101.4 \pm 0.7$ & $98.9 \pm 1.3$ & 2.39 \\
7 & $100.2 \pm 0.3$ & $99.3 \pm 0.6$ & 1.90 \\
8 & $99.9 \pm 0.7$ & $97.6 \pm 1.2$ & $2.34^{c}$ \\
9 & $99.8 \pm 0.5$ & $97.9 \pm 1.1$ & 2.22 \\
Mean & $99.4 \pm 0.6$ & $98.4 \pm 0.9$ & \\
\hline
\end{tabular}

Other components: ${ }^{a}$ red dye; ${ }^{b} 30 \mathrm{mg}$ of caffeine (500 mg of ASA); ${ }^{c}$ three layers tablet (white, green and yellow) containing $1 \mathrm{mg}$ of dexchlorpheniramine maleate, $10 \mathrm{mg}$ of phenylephrine chloridrate, $30 \mathrm{mg}$ of caffeine (400 mg of ASA). plus ASA, in the medicine, likewise the pharmacopoeia method that does not discriminate the two substances, as the actual pharmaceutical active substance is the salicylate to which ASA is hydrolyzed in the body.

If desired, to test if there is significant quantity of salicylic acid present in the medicine, the Trinder reaction can be performed before the alkaline hydrolysis. In this work development of blue color was not visually observed when the $\mathrm{Fe}(\mathrm{III})$ was added to the acidified non hydrolyzed solutions of the nine medicines.

Considering the obtained results, the method proposed in this work can be recommended for the determination of ASA in pharmaceutical preparations.

\section{Acknowledgments}

The authors would like to thank FAPESP, Fundação de Amparo à Pesquisa do Estado de São Paulo, CNPq, Conselho Nacional de Pesquisas Científicas e Tecnológicas and CAPES, Coordenação de Aperfeiçoamento de Pessoal de Nível Superior, for financial support.

\section{References}

1. Hammerschmidt, D.E.; J. Lab. Clin. Med. 1998, 132, 556.

2. Vane, J.R.; Nature New Biol. 1971, 231, 232.

3. Eccles, M; Freemantle, N. ; Mason, J.; Brit. Med. J. 1998, 316, 1303.

4. Marcus, A.J.; Broekman, M.J.; J. Lab. Clin. Med. 1998, 132, 446.

5. Yip, L.; Jastremski, M.; Dart, R.; J. Int. Care Med. 1997, 12, 66.

6. The United States Pharmacopoeia, $21^{\text {st }}$ ed., United States Pharmacopoeial Convention, Inc.: Rochville, 1985, p. 951.

7. Trinder, P.; Biochem. J. 1954, 57, 301.

8. Koupparis, M.A.; Anagnostopoulou, P.I.; J. Pharm. Biomed. Anal. 1988, 6, 35.

9. Glombitza, B.W.; Schmidt, P.C.; J. Pharm. Sci. 1994, 83, 751.

10. Martos, N.R.; Diaz, A.M.; Vallvey, L. F. C.; Anal. Lett. 2001, 34, 579.

11. Merckle P.; Kovar, K. A.; J. Pharm. Biomed. Anal. 1998, 17, 365.

12. Pirola, R.; Bareggi, S.R.; De Benedittis, G.; J. Chromatogr. 1998, 705, 309.

13. Rivas, G.A.; Calatayud, J.M.; Talanta 1995, 42, 1285.

14. Zhang, X.B.; Guo, C.C.; Jian, L.X.; Shen, G.L.; Yu, R.Q.; Anal. Sci. 2000, 16, 1285.

15. Pasekova, H.; Sales, M.G.; Montenegro, M.C.; Araújo, A.N.; Polasek, M.; J. Pharm. Biomed. Anal. 2001, 24, 1027.

16. Ferreira, V.J.F.; Cavalheiro, A.C.V.; Fagnani, E.; Moraes, M.; Pezza, L.; Pezza, H.R.; Melios, C.B.; Anal. Sci. 1999, 15, 249. 
17. Kubota, L.T.; Fernandes, J.C.B.; Rover Jr., L.; de Oliveira Neto, G.; Talanta 1999, 50, 661.

18. Martin, C.; Dominguez, E.; J. Pharm. Biomed. Anal. 1999, 19, 107.

19. Vila, M.M.D.C.; Tubino, M.; de Oliveira Neto, G.; J. AOAC Internat. 2001, 84, 1363.

20. Pereira, A.V.; Aniceto, C.; Fatibello, O.; Analyst 1998, 123, 1011.

21. Charette, J.D.; Zager, S.; Storrow, A.B.; Amer. J. Emerg. Med. 1998, 16, 546 .
22. Matias, F.A.M.; Vila, M.M.D.C.; Tubino, M.; Sensor Actuator B-Chem. 2003, 88, 60.

23. Eckschlager, K.; Errors, Measurement and Results in Chemical Analysis, Van Nostrand Reinhold Company: London, 1972, pp. 109-113.

Received: February 21, 2003

Published on the web: February 27, 2004

FAPESP helped in meeting the publication costs of this article. 